\title{
ISLAM DAN SOLIDARITAS SOSIAL: PERKEMBANGAN MASYARAKAT ISLAM PERIODE MADINAH
}

\author{
M. Yakub \\ Universitas Islam Negeri Sumatera Utara
}

\begin{abstract}
ABSTRAK
Solidaritas sosial hanya mampu dibangun dalam konsep kepemimpinan yang matang. Nabi Muhammad sebagai seorang pemimpin mampu menyatukan seluruh elemen masyarakat Madinah dan menjadikan Madinah menjadi kota yang memiliki tatanan sosial yang sangat baik. Ini ditunjukkan dari isi Piagam Madinah yang menjunjung tinggi nilai-nilai kebersamaan, tanggung jawab sosial, toleransi dan juga sikap saling menghormati. Karakter masyarakat Madinah telah tercipta dengan akhlak yang luhur dan sikap toleransi yang tinggi telah terjaga dengan baik ditengah-tengah masyarakat Madinah yang heterogen dan pluralistik. Tetapi, tidak terlepas juga Rasulullah mendapatkan gangguan baik dari kaum Yahudi, munafik dan kaum kafir Quraisy. Hijrah telah menjadi tolak ukur awal eksistensi umat Islam dalam menyampaikan pesan-pesan kedamaian dimulai dari kota Madinah.
\end{abstract}

\section{Kata Kunci : Solidaritas Sosial, Toleransi, Madinah, Hijrah}

\begin{abstract}
Social solidarity can only be built on mature leadership concepts. The Prophet Muhammad as a leader was able to unite all elements of the community of Medina and make Medina a city that has a very good social order. This is indicated by the contents of the Medina Charter which upholds the values of togetherness, social responsibility, tolerance and mutual respect. The character of the community of Medina has been created with noble character and high tolerance has been well maintained in the midst of a heterogeneous and pluralistic Medina society. However, it was not free that the Prophet received interference from both the Jews, the hypocrites and the infidels of Quraish. Hijrah has become the initial benchmark for the existence of Muslims in conveying messages of peace starting from the city of Medina.
\end{abstract}

\section{Key Words : Social Solidarity, Tolerance, Medina, Hijrah}

\section{PENDAHULUAN}

Islam yang di wahyukan kepada Nabi Muhammad Saw telah membawak bangsa arab yang semula terbelakang, bodoh, tidak beradap dan tidak terkenal,dan di abaikan oleh bangsa lain, menjadi bangsa yang maju, ia dengan cepat bergerak 
mengembangkan dunia,membina suatu ke budayaan dan peradaban yang sangat penting artinya dalam sejarah manusia hingga sekarang. Peradaban atau kebudayaan pada masa Rasulullah Saw. Yang paling dahsyat adalah perubahan social. Suatu perubahan mendasar dari masa kebobrokan moral menuju moralitas yang beradab.

Pertumbuhan dan perkembangan sebuah peradaban besar dunia, khususnya Islam dimualai dari hijrah. Hijrah dengan segala nilainya, hendaklah dicermati dan dikaji untuk melihat persoalan dimasa kini yang begitu kompleks, tidak hanya sebagai romantisme sejarah. Refleksi dari kontekstualisasi pemaknaan hijrah hendaknya mampu memberikan semangat baru bagi umat Islam untuk berubah, berkembang agar mampu senantiasa menghadapi tantangan. Madinah merupakan salah satu unsur pembentuk tata-sosial Islam yang di dalam Piagam Madinah tidak diragukan lagi kandungannya. Tata-sosial Islam bisa bermula di negeri atau kelompok manapun, tetapi ia akan merosot dan berubah menjadi tidak Islami jika ia tidak bergerak terus-menerus untuk mencakup seluruh ummat manusia. ${ }^{1}$

Tata sosial yang paling baik adalah tata sosial yang mengatur sebanyak mungkin aktivitas manusia, bukan yang sedikit. Banyak mengatur aktivitas manusia, dan juga banyak jenis manusianya (ras, kelompok, budaya, negara, dsb). Dan Piagam Madinah merupakan cerminan tata sosial yang menyeluruh, karena ia menjadi wadah bagi berbagai ras, klan, suku, agama, dan bangsa. Kesemuanya mempunyai tujuan yaitu membentuk sebuah kesepakatan untuk mencapai (meminjam istilah Watt), "the divine plan of salvation." Sehingga, dibutuhkan aturan yang mengatur tata-sosial di Madinah, yang juga tidak menafikkan akan rintangan dan halangan yang dinilai membahayakan kehidupan masyarakat di Madinah.

Robert N Bellah sebagai seorang sosiolog politik menyatakan bahwa Bukanlah Amerika yang memulai pemerintahan demokratis, akan tetapi justru nabi Muhammad telah melakukannya sejak 14 abad yang silam. Bellah membahas hal ini dalam perspektif modernitas, Menurut Bellah pada masa itu sebenarnya

\footnotetext{
${ }^{1}$ Ismail Raji' Al-Faruqi, Tauhid: Its Implications for Thought and Life, terj. Rahmani Astuti, (Bandung: Pustaka, 1988), hlm. 109

${ }^{2}$ W. Montgomery Watt, Islamic Political Thought, (North America: Edingburgh University Press, 1968), hlm. 10
} 
terlalu dini untuk menerapkan pemerintahan demokratis. Muhammad tidak memulai dakwahnya dalam sebuah kerajaan dunia yang besar dan terorganisasikan dengan baik, tetapi hanya dalam sebuah masyarakat kesukuan yang belum mencapai struktur politik yang dapat disebut negara. Ia tidak terlalu harus banyak menjalin hubungan dengan tatanan politik yang ada untuk menciptakan hubungan yang baru. Lebih jauh, dalam sebuah masyarakat di mana hampir setiap hubungan penting dinyatakan dalam kerangka ikatan keluarga. Muhammad telah mengembangkan suatu organisasi politik yang dapat mengatasi ikatan ikatan keluarga. ${ }^{3}$

Salah satu kriteria masyarakat madani yang terwujud di Madinah adalah keseimbangan antara hak dan kewajiban sosial. Setiap anggota masyarakat memiliki hak dan kewajiban yang seimbang untuk menciptakan kedamaian, kesejahteraan dan keutuhan masyarakat. Konsep zakat, infaq, shadaqah dan hibah bagi umat Islam serta jizyah dan kharaj bagi non muslim, merupakan wujud keseimbangan yang adil dalam masalah tersebut. Keseimbangan hak dan kewajiban itu berlaku pada seluruh aspk kehidupan sosial, sehingga tidak ada suatu kelompok tertentu yang diistimewakan dari kelompok sosial lainnya sekedar karena ia mayoritas. ${ }^{4}$

Madinah menjadi kota tempat Nabi menjalankan pemerintahannya, hal yang perlu dilihat ialah sistem politik Rasulullah dalam hal menyatukan masyarakat. Juga bagaimana Rasulullah mengatur segala sistem baik, sosial, ekonomi ataupun budaya yang bisa dikatakan belum pernah teratur sebelum kedatangan Nabi. Sikap kesukukuang yang dimiliki oleh bangsa Arab menjadi tantangan tersendiri bagi Nabi Muhammad dalam menghilangkan sikap primordialisme dan feodalisme. Untunglah masyarakat Madinah memiliki sikap yang jauh berbeda dari masyarakat Mekkah yang sangat keras. Masyarakat Madinah mampu menerima Nabi dengan senang hati, ${ }^{5}$ dan segera menerima Islam

\footnotetext{
${ }^{3}$ Robert N. Bellah, Beyond Belief, cet. I, (Jakarta: Paramadina, 2000), hlm. 210

${ }^{4}$ Akram Dhiyauddin Umar, Masyarakat Madani. Cet. I ( Jakarta: Gema Insani,119) hlm. 118

${ }^{5}$ Nabi bertemu dengan sekelompok masyarakat Yatsrib sebanyak 13 orang di Aqabah yang datang ke Makkah dengan maksud melaksanakan haji mengikuti jejak Nabi Ibrahim AS. Mereka menyatakan memeluk Islam dan berjanji menyebarkannya kepada keluarga mereka. Peristiwa ini disebut Baiatul Aqabah (Perjanjian Aqabah) I. Setahun kemudian mereka datang lagi berjumlah 73 orang bertemu di tempat yang sama. Selain bersumpah setia memeluk dan
} 
dengan ikhlas. Bahkan rela mengorban apapun demi Nabi dan para sahabatnya yang datang dari Mekkah.

Maka, tentulah yang menjadi hal yang unik yang harus dilihat adalah solidaritas sosial yang dibangun oleh Rasulullah dalam membentuk tatanan masyarakat madani yang sesuai dengan al-quran dan sunnahnya, dan itu dimulai ketika Nabi memulai kepemipinannya di Madinah.

\section{PEMBAHASAN}

\subsection{Character Building : Pembentukan Awal Masyarakat Madinah}

Madinah adalah tempat dimana Nabi Muhamad Saw mulai membangun peradaban Islam untuk pertama kalinya. Pada era ini Nabi Muhammad Saw sebagai manusia pilihan dari Allah Swt menggunakan legitimasi kenabiannya untuk membawa masyarakat Madinah kejalan menuju Tuhan Yang Maha Esa. Di kota inilah awal baru Nabi Muhammad dalam membangun kekuasaan yang dipimpin langsung oleh beliau kearah masyarakat Madani, oleh sebab itulah kota ini yang sebelumnya bernama Yastrib dirubah oleh Nabi menjadi Madinah.

Jika dikampung halaman Nabi_Mekkah_, dakwah ataupun seruannya ditolak oleh kaumnya, maka di Madinah Nabi diterima dengan hangat dan disambut oleh seluruh masyarakat Madinah. Mengutip buku Prof K. Ali yang berjudul Sejarah Islam (Tarikh Pramodern) dalam menggambarkan kebijakan awal Nabi, bahwa pada saat tiba di Madinah, masyarakat terbagi dalam berbagai golongan (kelompok). Kelompok Muhajirin, pengikut Nabi yakni orang-orang mukmin yang meninggalkan tanah kelahiran mereka dan turut berhijrah ke Madinah. Kelommpok Anshar ialah penikut Nabi penduduk asli Madinah yang telah menerima dengan senang hati Nabi dan rombongannya dari kkelompok Muhajirin. ${ }^{6}$

Kaum _jika tidak disebut kelompok_ memiliki peran besar dalam dakwah Nabi. Mereka adalah orang-orang yang rela meninggalkan kampung halaman,

mendakwahkan Islam mereka juga mengajak nabi hijrah ke Yatsrib dan menjadikannya sebagai pemimpin. Peristiwa inidisebut Baiatul Aqabah II. Kedua perjanjian ini merupakan kontrak sosial dan politik yang menjadi faktor pendorong lahirnya kekuasaan politik Nabi Muhammad di Kota Madinah (Yatsrib) pada tahun 622 M.Lihat : Philip K. Hitti, History of the Arab, (Jakarta: Serambi, cet. I, 2008), hlm. 145

${ }^{6}$ K. Ali, Sejarah Islam (Tarikh Pramodern), (Jakarta : PT RajaGrafindo Persada, 2003) hlm. 62 
baik harta maupun keluarga mereka yang ada di Mekkah demi mengikuti Nabi di Madinah, kaum ini terdiri dari sahabat-sahabat Nabi yang berjuang dan telah terukir nama-namanya di sejarah seperti Abu Bakar, Umar, Usman, Ali dan lainnya. Sedangkan kaum Anshar adalah orang-orang yang rela menolong dan membantu segala kebutuhan Nabi dan para sahabat beliau selama ereka menetap di Madinah, baik dalam hal moril maupun materil, oleh karena itu mereka disebut kaum Anshar (umat penolong). ${ }^{7}$

Ada dua kelompok lagi selain Muhajirin dan Anshar, yaitu masyarakat Madinah penyembah berhala dan Yahudi. Masyarakat Madinah penyembah berhala turut menyambut Nabi kedatangan Nabi. Seluruh masyarakat Madinah, baik yang beriman maupun yang tidak beriman, semuanya bersedia melindungi dan membela Nabi Muhammad. ${ }^{8}$ Sedangkan penganut agama Yahudi di Madinah mempunyai pendirian dan sikap yan berbeda-beda. Mereka bersama dengan masyarakat Madinah lainnya turut menyambut kehadiran Nabi. Pada mulanya Nabi mengakui keberadaan agama mereka, bahkan Nabi menggolongkan mereka sebagai "ahli Kitab". Sebagai strategi untuk menjalin persahabatan Nabi bahkan melestarikan sebagian kebiasaan dan praktek-praktek keagamaan mereka. Sementara sebagian penganut Yahudi senantiasa berusaha menggeser kepemimpinan Nabi. Tetapi ketika terbukti bahwa mereka tidak berhasil menggeernya, perlahan-lahan mereka mengurangi dukungannya terhadap Nabi bahkan mereka berusaha menjalin kerja sama dengan Quraisy Mekkah untuk memusuhi Islam. ${ }^{9}$

Pekerjaan besar yang dilakukan Rasulullah Saw dalam periode ini adalah pembinaan terhadap masyarakat islam yang baru terbentuk. Karena masyarakat merupakan wadah dari pengembangan kebudayaan, maka berbarengan dengan pembinaan masyarakat itu diletakkan pula dasar-dasar kebudayaan Islam. Sehingga terwujud sebuah masyarakat Islam yang kokoh dan kuat. Dasar-dasar

\footnotetext{
${ }^{7}$ Ibid., hlm. 62

${ }^{8}$ Tetapi setelah Islam semakin berkembang pesat, kelompok nonmuslim Madinah mulai cemas dengan eksistensi Nabi. Abdullah bin Ubay adalah tokoh nonmuslim yang menaruh benci dan iri hati atas supremasi politik Nabi. Ia terkenal sangat licik dan mempunyai sejumlah pengikut yang terdiri dari orang-orang munafik yang berusaha menentang Nabi secara sembunyi-sembunyi. Mereka adalah musuh-musuh Islam yang lebih berbahaya daripada musuh Islam yang tampak. Karena itulah Nabi sangat hati-hati dan mewaspadai tipu daya mereka. Ibid., hlm. 63

${ }^{9}$ Ibid., hlm. 64
} 
kebudayaan yang diletakkan oleh Nabi Muhammad Saw itu pada umumnya merupakan sejumlah nilai dan norma yang mengatur manusia dan masyarakat dalam hal yang berkaitan dengan peribadatan, sosial, ekonomi dan politik yang bersumber dari Al-quran dan Hadist. ${ }^{10}$

Menurut Prof. K. Ali, kebijakan politik yang pertama kali ditempuh Nabi adalah upaya mengahapuskan jurang pemisah antarsuku-suku dan berusaha menyatukan seluruh penduduk Madinah sebagai suatu kesatuan masyarakat. Pada sisi lainnya Nabi berusaha mempererat hubungan antara masyarakat Anshar dengan Muhajirin, melalui ikatan persaudaraan antar mereka. Agaknya Nabi sangat menyadari bahwa dasar fondasi imperium islam tidak akan kuat kecuali didasari oleh kerukunan dan dukungan dari seluruh lapisan masyarakat yang majemuk yang sangat diperlukan adalah sikap toleransi antar umat beragama. Dalam hal ini kebijakan yang ditempuh Nabi bersandar pada prinsip "saling hidup menghidupi",11

Syed Mahmudunnasir dalam bukunya Islam Konsepsi dan Sejarahnya, lebih kompleks lagi menjelaskan peran kenabian di Rasulullah Saw di Madinah. Beliau mengatakan bahwa Nabi Muhammad Saw mendirikan suatu negara _di Madinah_ atas dasar prinsip-prinsip kesamaan, kebebasan, dan persaudaraan. Bangsa Arab, bangsa Yahudi dan semua warga negara persemakmuran Islam yang baru itu ditempatkan pada pijakan yang sama, diizinkan mengambil bagian secara bebas dan sederajat di dalam pendirian suatu struktur sosio-politik yang baru dan di dalam memajukan kemanusiaan bagi cita-cita moral yang lebih sempurna dan lebih kaya. Tidak ada prasangka-prasangka nasional atau rasial, tidak ada larangan-larangan karena warna kulit, tidak ada kepentingan pribadi, tidak ada kependetaan dan kebangsawanan turunan di dalam persemakmuran Islam. Tidak ada keuntungan-keuntungan khusus atau negara yang tertinggi. Nilai manusia yang hakiki ditentukan bukan oleh pangkatnya atau nasib baiknya, melainkan oleh akhlak dan kemampuannya. Setiap orang diberi peluang dan

\footnotetext{
${ }^{10}$ Team Penyusun Texbook Sejarah dan kebudayaan Islam Direktorat Jenderal Pembinaan Kelembagaan Agama Islam Departemen Agama RI, Sejarah dan Kebudayaan Islam (Ujungpandang: Pro-yek Pembinaan Perguruan Tinggi Agama IAIN “Alauddin' Ujungpandang 1981/1982), hlm. 46-47. Dalam Siti Maryam Dkk, Sejarah Peradaban Islam, Dari Masa Klasik Hingga Modern, (Yogyakarta: LESFI, 2004) hlm. 30-31

${ }^{11}$ K. Ali, Sejarah Islam.., hlm. 65-66
} 
ruang gerak untuk menggunakan bakat-bakat dan kemampuan-kemampuannya di jalan yang menurut dia sesuai, atau dia diberi pangkat dan kedudukan yang cocok dengan kemampuannya. ${ }^{12}$

Zuhairini, dalam buku Sejarah Pendidikan Islam, mengambil perspetif yang lebih halus dibandingkan dengan bahasa politis, beliau lebih mengambil kata pendidikan. Adapun titik tekan pendidikan Islam pada periode Madinah ialah : ${ }^{13}$

1. Pembentukan dan pembinaan masyarakat baru, menuju satu kesatuan sosial dan politik. Dalam hal ini Nabi melaksanakan pendidikan sebagai berikut:

a. Nabi mengikis habis sisa-sisa permusuhan dan pertengkaran antar suu, dengan jaan mengikat tali persaudaraan di antara mereka.

b. Untuk memenuhi kebutuhan hidup sehari-hari, Nabi menganjurkan kepada kaum Muhajirin untuk usaha dan bekerja sesuai dengan kemampuan dan pekerjaan masing-masing seperti waktu di Madinah.

c. Menjalin kerja sama dan tolong menolong dalam membentuk tata kehidupan masyarakat yang adil dan makmur.

d. Shalat Jum'at sebagai media komunikasi seluruh umat Islam.

2. Pendidikan sosial dan kewarganegaraan. Pendidikan ini dilaksanakan melalui:

a. Pendidikan ukhuwah (persaudaraan) antar kaum muslimin

b. Pendidikan kesejahteraan sosial dan tolong menolong.

c. Pendidkan kesejahteraan keluarga kaum kerabat.

3. Pendidikan anak dalam Islam. Rasulullah selalu mengingatkan kepada umatnya, antara lain:

a. Agar selalu menjaga diri dan anggota keluarga dari api neraka.

b. Agar jangan meninggalkan anak dan keturunan dalam keadaan lemah dan tidak berdaya menghadapi tantangan hidup.

c. Orang yang dimuliakan oleh Allah adalah orang yang berdoa agar dikaruniai keluarga dan anak keturunan yang menyenangkan hati. ${ }^{14}$ hlm. 130

${ }^{12}$ Syed Mahmudunnasir, Islam dan Konsepsi Sejarahnya, (Bandung : CV Rosda, 1988) $34-50$

${ }^{13}$ Zuhairini, dkk., Sejarah Pendidikan Islam, (Jakarta : Departemen Agama, 1986) hlm. 


\section{Pendidikan Hankam Dakwah Islam.}

Dalam rangka memperkokoh masyarakat dan negara baru itu, Nabi Muhammad Saw segera meletakkan dasar-dasar kehidupan bermasyarakat. Dasar pertama, pembangunan masjid, selain untuk tempat shalat, masjid juga sebagai sarana penting untuk mempersatukan kaum muslimin dan mempertalikan jiwa mereka, disamping tempat bermusyawarah merundingkan masalah-masalah yang dihadapi. Masjid pada masa Nabi bahkan juga berfungsi sebagai pusat pemerintahan. ${ }^{15}$ Dasar kedua, adalah ukhuwah islamiyah, persaudaraan sesama muslim. Nabi mempersaudarakan antara golongan Muhajirin dengan Anshar. Dengan demikian, diharapkan setiap muslim merasa terikat dalam suau persudaraan dan kekeluargaan. Apa yang dilakukan Rasulullah ini telah membentuk persaudaraan yang baru, yaitu persaudaraan berdasarkan agama, menggantikan persaudaraan berdasarkan darah atau suku/golongan. Dasar ketiga, hubungan persahabatan dengan pihak-pihak lain yang tidak beragama Islam. Di Madinah, di samping orang-orang Arab Islam, juga terdapat golongan masyarakat Yahudi dari orang-orang Arab yang masih menganut agama nenek moyang mereka. ${ }^{16}$

Dalam konteks sosio-kultural Nabi Muhammad telah berhasil membangun fondasi awal yang sangat kokoh. Terbukti hanya dalam jangka waktu yang sebentar beliau telah berhasil membangun persaudaraan yang begitu kuat, dan menghilangkan sikap-sikap sekterianisme atau sikap kesukuan. Dalam sekejap Muhammad sang pemimpin Madinah juga telah mempersatukan berbagai lapisan,

${ }^{14}$ Adapun bentuk-bentuk pendidikan anak dalam Islam sebagaimana digambarkan dalam surat Luqman ayat 13-19 sebagai berikut : 1) Pendidikan tauhid, 2) Pendidikan Shalat, 3) Pendidikan sopan santun dalam keluarga, 4) Pendidikan sopan santun dalam masyarakat, 5) Pendidikan kepribadian. Lihat : Zuhairini, dkk., Sejarah.., hlm. 47

${ }^{15}$ Lembaga utama dan pertama yang dibangun Rasulullah dalam rangka pembinaan masyarakat ini adalah masjid. Masjid pertama yang dibangun oleh Rasululah ialah masjid Quba, selang beberapa hari kemudian Masjid Nabawi dibangun setelah Rasulullah tiba di Yastrib. Sebelum Islam, suku-suku Arab biasa menyediakan suatu tempat untuk pertemuan. Ditempat itu mereka mempertontonkan sihir, menyelenggarakan upacara perkawinan, melakukan transaksi jual beli dan kegiatan lainnya. Masjid yang dibangun Rasulullah, selain disediakan untuk tempat beribadah, juga digunakan sebagai tempat pertemuan Rasulullah dengan para sahabatnya. Di tempat ini pula kaum muslimin melakukan kegiatan belajar, mengadili suatu perkara, berjual beli, bermusyawarah untuk menyelesaikan persoalan-persoalan umat dan berbaai kegiatan lainnya. Lihat : Siti Maryam Dkk, Sejarah.., hlm. 31

${ }^{16}$ Badri Yatim, Sejarah Peradaban Islam, (Jakarta : PT. Grafindo Persada, 2001) hlm. $25-26$ 
baik Islam, Yahudi maupun Nasrani, baik si kaya maupun si miskin. Doktrin yang dibangun dalam tatanan ini ialah konsep ketakwaan yang selalu menjadi dakwah utama Muhammad Saw. Hingga terbentuk pula asas-asas masyarakat Islam yang telah di bangun oleh Nabi Muhammad Saw.

Adapun beberapa asas yang telah berhasil diletakkan oleh Nabi Muhammad Saw ialah antara lain, al-ikha, al-musawah, al-tasamuh, al-tasyawur, al-ta'awun,dan al-adalah. Seperti yang dijelaskan dalam buku Siti Maryam dkk, Sejarah Peradaban Islam, Dari Masa Klasik Hingga Modern, yaitu sebagai berikut:

Al-Ikha (persaudaraan) merupakan salah satu asas penting masyarakat Islam yang diletakan oleh Rasul. Bangsa Arab yang dahulunya lebih menonjolkan identitas kesukuan, setelah mereka memilih Islam diganti dengan identitas baru yaitu Islam. Demikian pula loyalitas kabilah atau sukuditukar dengan loyalitas Islam. Atas dasar ini pulalah Rasulullah mempersaudarakan kaum Muhajirin dengan kaum Anshar. ${ }^{17}$

Al-musawah (persamaan). Rasulullah dengan tegas mengajarkan bahwa seluruh manusia adalah keturunan Adam yang diciptakan Tuhan dari tanah. Seorang Arab tidak lebih mulia dari seorang (bukan Arab), demikian pulak sebaliknya, kecuali karena ketakwaannya. Berdasarkan asas ini setiap warga masyarakat memiliki hak kemerdekaan dan kebebasan atau al-hurriyah. Oleh karena itu, Rasulullah sangat memuji dan menganjurkan para sahabatnya untuk memerdekakan hamba-hamba sahaya yang dimiliki oleh bangsawan-bangsawan Quraisy. Al-tasamuh (toleransi) sebagai asas masyarakat Islam dibuktikan antara lain dengan Piagam Madinah. Umat Islam siap berdampingan secara baik dengan umat Yahudi. Mereka mendapat perlindungan dari negara dan bebas

${ }^{17}$ Banyak kaum Muhajirin datang ke Madinah dalam keadaan miskin, karena harta benda dan kekayaan mereka ditinggalkan di Mekkah. Yang mereka bawa hanyalah harapan dan keyakinan. Oleh karena itu Rasulullah mempersaudarakan kaum Muhajirin dan kaum Anshar yang dengan ikhlas bersedia menolong mereka. Abu Bakar dipersaudarakan dengan Haritsah ibn Zaid, Ja'far bin Abi Thalib dengan Mu'adz bin Jabal, Umar bin Khattab dengan 'Itbah bn Malik dan lain-lain. Demikianlah keluarga-keluarga Muhajirin dan Anshar dipertalikan dengan ikatan persaudaraan berdasarkan agama, menggantikan persaudaraan yang berdasarkan kesukuan. Pada mulanya, hukum persaudaraan itu sama dengan persaudaraan senasab, termasuk di antaranya mengenai harta pusaka. Bagi orang-orang yang masuk Islam dalam keadaan miskin disediakan tempat tinggal di shuffah masjid, sehingga kemudian mereka di kenal dengan ashhab al-shuffah. Keperluan hidup mereka ditanggung bersama oleh kaum Anshar dan Muhajirin yang sudah berkecukupan. Lihat : Siti Maryam Dkk, Sejarah.., hlm. 32 
melaksanakan ajaran agamanya. Akan tetapi, toleransi umat Islam itu direspon oleh mereka dengan sikap pengkhianatan terhadap piagam Madinah yang telah disepakati bersama. Setelah terbukti mereka mengusik keimanan orang-orang Islam, berusaha mencelakai Rasulullah dan bersekongkol dengan kafir Quraisy, satu persatu kabilah-kabilah Yahudi itu diusir dari Madinah. Al-tasyawur (musyawarah. Walaupun Rasulullah mempunyai status yang tinggi dan terhormat dalam masyarakat, acapkali beliau meminta pendapat para sahabat dalam menghadapi dan menyelesaikan persoalan-persoalan yang berkaitan dengan urusan dunia dan sosial budaya. Manakala argumentasi para sahabat itu dianggap benar, tidak jarang beliau mengikuti pendapat mereka. Al-ta'awun (tolongmenolong) dalam berbuat kebajikan merupakan kewajiban setiap muslim. Tolong menolong sesama muslim, antara lain telah ditunjukkan dengan pihak lain sesama penduduk Madinah, Piagam Madinah merupakan bukti kuat berkaitan dengan pelaksanaan prinsip ini. Adapun kemudian Yahudi diusir dari Madinah, penyebabnya karena mengkhianati piagam tersebut. Al-adalah (keadilan) berkaitan erat dengan hak dan kewajiban setiap individu dalam kehidupan bermasyarakat sesuai dengan posisi masing-masing. Di satu sisi seseorang hendaknya memperoleh haknya, sementara pada sisi lain berkewajiban memberikan hak orang lain kepada yang berhak menerimanya. ${ }^{18}$

Dengan berbagai aspek Rasulullah berhasil membangun karakter umat di Madinah yang sebelum Islam hadir masih tersentuh sikap-sikap Jahiliyah. Dengan kemauan keras kaum Anshor yang ingin berubah, maka Rasul dengan mudah membentuk akhlak mereka. Inilah yang menjadi poin utama yang membuat Rasul bisa mengambil hati para kaum Anshor dikarenakan hati mereka yang telah menerima kebenaran Nabi bahkan sebelum Nabi sampai ke kota mereka.

\subsection{Piagam Madinah dan Pembentukan Civil Society}

Berbicara tentang Pembentukan Negara Madinah dan Piagam Madinah (Konstitusi Madinah), maka tidak dapat dipisahkan dengan hijrah Rasulullah SAW ke Madinah. Karena hijrah adalah suatu fakta sejarah masa lalu yang tidak dapat dipungkiri dan dapat dijadikan khazanah pemikiran Islam masa kini, serta

\footnotetext{
${ }^{18}$ Ibid., hlm. 33
} 
merupakan tonggak sejarah umat muslimin berdirinya negara Madinah, Konstitusi Madinah yang universal dan diterima oleh semua golongan dan lapisan masyarakat didalamnya mengatur pola hidup bersama antar kaum muslim di satu pihak dengan orang non muslim pada pihak lain. ${ }^{19}$ Muhammad saw dapat menempatkan diri sebagai pemimpin Madinah ditengah-tengah komunitas lain, Islam ditanamkan oleh beliau sebagai satu kesatuan agama, sosial budaya dan politik. Muhammad mampu menjadikan Islam sebagai agama yang menghasilkan rekonsiliasi ditengah keanekaragaman komunitas. ${ }^{20}$ Antara kaum Muhajirin, kaum Anshor dengan orang Yahudi membuat suatu perjanjian tertulis yang berisi pengakuan atas agama-agama mereka dan harta-harta mereka dengan syaratsyarat timbal balik. $^{21}$

Tujuan utama dalam pembuatan Piagam Madinah $^{22}$ ialah untuk menggalang kesatuan yang harmonis. Piagam ini memberi perlengkapan bagi landasan suatu negara kota, suatu persemakmuran, dan bagi suatu bangsa yang didasarkan atas ikatan kesatuan agama dan keimanan, kesamaan dan demokrasi. Nabi Muhammad berhasil dalam memebangkitkan suatu rasa kesatuan bangsa di antara suku-suku yang selalu berperang. Piagam ini menunjukkan kebesaran sejati orang itu_ seorang pemikir ulung tidak hanya bagi zamannya, tetapi juga sepanjang masa. ${ }^{23}$ Dengan perjanjian itu, kota Madinah menjadi Madinah alHaram dalam arti yang sebenarnya. Setiap penduduk bertanggung jawab dan memikul kewajiban bersama untuk menyelenggarakan keamanan dan membela serta mempertahankan negeri terhadap ancaman dan serangan musuh dari manapun juga datangnya, ini menjadi sebuah peristiwa baru dalam dunia politik

${ }^{19}$ Soekarna Karya dkk, Ensiklopedi Mini Sejarah dan Kebudayaan Islam, (Jakarta: Logos. 1996), hlm. 320

${ }^{20}$ T. W. Arnold, The Preiching of Islam, (Lahore: Ashraf Printing Press, 1979) hlm. 36

${ }^{21}$ Muhammad Husen Haikal, Sejarah Hidup Muhammad, (Jakarta: PT.Pustaka Litera Antar Nusa, 2000) h. 199.

${ }^{22}$ Mengenai kapan penyusunan naskah Piagam Madinah ini tidak pasti, mengenai waktu dan tanggalnya. Apakah waktu pertama Hijriyah atau sebelum waktu perang Badar atau sesudahnya. Menurut Watt, para sejarah umumnya berpendapat bahwa piagam itu dibuat pada permulaan periode Madinah tahun pertama hijriyah. Well Husen menetapkannya sebelum perang Badar sedangkan Hurbert Grimne berpendapat bahwa piagam itu dibuat setelah Perang Badar. Dan masih banyak lagi tokoh yang berpendapat tentang kapan penyusunan Piagam Madinah. Lihat : J. Suyuti, Prinsip-Prinsip Pemerintah dalam Piagam Madinah Ditinjau dari Pandangan al-Qur'an, (Raja Grafindo Persada: Jakarta, 1995) hlm. 87-88

${ }^{23}$ Syed Mahmudunnasir, Islam.., hlm. 131 
dan peradaban manusia. Sementara kaum muslimin dapat menjalankan syariat agamanya dengan aman tanpa gangguan. ${ }^{24}$

Dalam Piagam tersebut dirumuskan kebebasan beragama, hubungan antar kelompok, kewajiban mempertahankan kesatuan hidup dengan membangun tatanan hidup bersama yang mantap dan riil dengan mengikutsertakan semua golongan sekalipun berbeda ras, keturunan, golongan dan agama. ${ }^{25}$ Menurut Harun Nasution, Piagam Madinah tersebut mengandung aturan pokok tata kehidupan bersama di Madinah, agar terbentuk kesatuan hidup di antara seluruh penghuninya. Kesatuan hidup ini dipimpin oleh Muhammad SAW sendiri. Kesepakatan contract social inilah yang menjadi dokumen konstitusi bagi lahirnya negara yang berdaulat. Dengan demikian, di Madinah Nabi Muhammad bukan hanya mengemban tugas-tugas keagamaan sebagai Rasulullah, melainkan juga sebagai kepala Negara. ${ }^{26}$

Di dalam Piagam Madinah terdapat 47 butir pasal, ${ }^{27}$ yang secara de facto telah menjadi sebuah konstitusi negara yang mengatur hubungan setiap masyarakat Madinah. Dari 47 butir pasal maka bisa disimpulkan beberapa poin yang bisa diambil dalam kebijakan Piagam Madinah, yaitu :

Pertama, seluruh masyarakat yang turut menandatangani piagam ini bersatu membentuk satu kesatuan bangsa. Kedua, jika salah satu kelompok yang turut menandatangani piagam ini diserang oleh musuh, maka kelompok yang lain harus membelanya dengan menggalang kekuatan gabungan. Ketiga, tidak satu kelompok pun diperkenankan mengadakan persekutuan dengan kafir Quraisy atau memberikan perlindungan kepada mereka atau membantu mereka mengadakan perlawanan terhadap masyarakat Madinah. Keempat, orang Islam, Yahudi dan seluruh warga Madinah yang lain bebas memeluk agama dan keyakinan masingmasing dan mereka dijamin kebebasannya dalam menjalankan ibadah sesuai dengan agama dan keyakinan masing-masing. Tidak seorangpun diperkenankan mencampuri urusan agama lain. Kelima, urusan pribadi atau perseorangan, atau

\footnotetext{
${ }^{24}$ Siti Maryam Dkk, Sejarah hlm. 31

${ }^{25}$ Ahmad Sukardja, Piagam Madinah dan UUD 1945, (Jakarta: UI Press, 1995) hlm. 3

${ }^{26}$ Harun Nasution, Islam di Tinjau dari berbagai Aspek, Jilid.I. (Jakarta: UI Press, 1985) hlm.50

27 Naskah lengkap Piagam Madinah dapat dibaca dalam Muhammad Husen Haikal, Sejarah Hidup Muhammad, (Jakarta: PT.Pustaka Litera Antar Nusa, 2000) hlm. 225-227
} 
perkara-perkara kecil kelompok nonmuslim tidak harus melibatkan pihak-pihak lain secara keseluruhan. Keenam, setiap bentuk penindasan dilarang. Ketujuh, mulai hari ini segala bentuk pertumpahan darah, pembunuhan, dan penganiayaan diharamkan diseluruh negeri Madinah. Kedelapan, Muhammad, Rasulullah, menjadi kepala Republik Madinah dan memegang kekuasaan peradilan yang tinggi. $^{28}$

Lebih menyimpulkan lagi, Munawir Syazali menyatakan bahwa sistem pemerintahan Negara Madinah secara keseluruhan dengan konstitusinya menganut paham Desentralisasi. Masalah intern kelompok diselesaikan oleh kelompok masing-masing, kecuali menyangkut masalah yang berhubungan dengan kelompok lain. Masalah tersebut ditangani oleh Rasulullah. Menurut beliau prinsip dasar piagam ini ialah : Pertama, semua pemeluk Islam, meskipun berasal dari banyak suku, tetapi merupakan satu komunitas. Kedua, hubungan antara anggota komunitas Islam dengan anggota komunitas yang lain didasarkan atas prinsip-prinsip. Ketiga, bertetangga baik. Keempat, saling membantu dalam menghadapi musuh bersama. Kelima, membela mereka yang teraniaya. Keenam, saling menasehati, dan ketujuh menghormati kebebasan beragama. ${ }^{29}$ Melihat keterangan-keterangan dari Munawir Syazali di atas, dengan demikian, dapat dikatakan bahwa konsep Piagam Madinah, yang dicetuskan oleh Rasulullah merupakan konsep yang ideal untuk sebuah negara dalam Islam. ${ }^{30}$

Menurut Prof. K. Ali, Piagam Madinah ini sangat besar artinya dalam sejarah kehidupan politik umat Islam. Ia dipandang sebagai undang-undang dasar tertulis yang pertama sepanjang sejarah peradaban dunia. Sebelum Nabi Muhammad, para penguasa dunia tidak menyertakan undang-undang tertulis untuk mengatur dasar-dasar kekuasaannya. Bahwa Muhammadlah tokoh pertama yang menyadari arti pentingnya keterlibatan rakyat dan dukungan mereka dalam suatu sistem administrasi negara. Selain itu, piagam ini juga menunjukkan bahwa

\footnotetext{
${ }^{28}$ K. Ali, Sejarah.., hlm. 66-67

${ }^{29}$ Munawir Syazali, Islam dan Tata Negara, (Jakarta: UI Press, 1990) hlm. 15

${ }^{30}$ Muhammad Thahir Azhari mengemukakan konsep Negara dalam Islam Nomokrasi (negara hukum) bukan teokrasi. Beliau mengemukakan negara hukum (nomokrasi) Islam memiliki prinsip-prinsip umum sebagai berikut: 1) Prinsip kekuasaan sebagai Amanah. 2) Prinsip keadilan. 3) Prinsip Persamaan. 4) Prinsip pengakuan dan perlindungan terhadap HAM. 5) Prinsip peradilan bebas. 6) Prinsip Perdamaian. 7) Prinsip Kesejahteraan. 8) Prinsip ketaatan rakyat. Lihat: Muhammad Thahir Azhary, Negara Hukum, Cet. I., (Jakarta: Bulan Bintang, 1992), hlm.34
} 
Muhammad bukanlah hanya sebagai penyebar agama (Rasul), tetapi beliau sekaligus seorang negarawan yang besar. Negara Madinah membuktikan bahwa Nabi Muhammad adalah negarawan terbesar, tidak hanya pada zamannya tetapi terbesar sepanjang sejarah. Pasal-pasal yang dirumuskan dalam Piagam Madinah menunjukkan bahwa Nabi Muhammad tidak hanya bermaksud memperkuat kekuasaannya untuk menghadapi serangan musyrik Mekkah, tetapi tujuan yang utama justru untuk menggalang kerukunan bagi warga negara di Kota Madinah. ${ }^{31}$

Merujuk ke Piagam Madinah, secara eksplisit tertulis nama beberapa golongan dan beberapa suku. Nampaknya, Rasulullah sangat mengetahui tentang keadaan dan politik setiap kelompok tersebut. Nabi Muhammad SAW dapat menepatkan diri sebagai pemimpin Madinah di tengah-tengah berbagai suku yang mengamininya sebagai pemimpin masyarakat. Islam ditanamkan oleh beliau sebagai satu kesatuan Agama dan Politik, Rasulullah berhasil menciptakan satu bangsa di bawah satu naungan kepemimpinan, suatu perwujudan dari gagasan besar berupa prinsip kehidupan nasional Arabia, dan beliau mampu menjadikan Islam sebagai agama yang menghasilkan rekonsiliasi. ${ }^{32}$ Dan menjunjung tinggi HAM, sekaligus pencetus konsep HAM pertama di dunia secara yuridis formal. ${ }^{33}$

Piagam Madinah adalah konsep kenegaraan yang mumpuni dari sang Rasul. Piagam Madinah juga sering disebut konstitusi tertulis pertama di dunia hingga diikuti oleh dunia hingga saat ini. Eksistensi dari Piagam Madinah ini tentunya menjadi panduan utuh bagi kepemimpinan Rasul, dengan adanya Piagam Madinah ini Rasulullah memiliki otoritas ataupun legitimasi yang tinggi pada manusia yang dipimpinnya. Jika pada awal kedatangannya di Madinah beliau telah berhasil menyatukan kaum Muhajirin dan Anshar maka dengan adanya

\footnotetext{
${ }^{31}$ Ibid., hlm. 68

${ }^{32}$ Muhammad Husen Haikal, Sejarah Hidup.., hlm. 199

33 Walaupun menurut penyelidikan Ilmu pengetahuan, sejarah hak-hak asasi manusia barulah tumbuh dan berkembang pada masa John Locke dan Rowseau (tokoh hukum alam). Merekalah yang memberikan inspirasi kepada revolusi negara-negara besar untuk mencantumkan di dalam konstitusinya. Untuk pertama kali dengan resmi dipakai dalam Declaration of Indefedence (Amerika) tahun 1776, atas jasa Thomas Jeferson. Kemudian menjadi Konstitusi Negara Amerika tahun 1897. kemudian diikuti Perancis tahun 1791. belgia tahun 1881, dan akhirnya diikuti PBB melalui Universal Declaration of Human Rights tanggal 10 Desember 1948. Di Indonesia UUD 45 baru ada di 4 pasal dari 37 pasal yaitu pasal 27 ayat 1 dan 2. pasal 28, pasal 29 dan pasal 31. Padahal kalau mereka mau jujur justru mereka itu diilhami oleh al-Qur an (14 abad yang lalu) dan Piagam Madinah (abad $6 \mathrm{M}$ ) Lihat QS. Al-Hijr 23 dan Al-Qaaf: 43 tentang hak hidup. Kemerdekaan dan keamanan pribadi. Al-Baqarah 178 tentang Qishash.Lihat : Dalizar, Konsep Al-Quran Tentang Hak Asasi Manusia, (Jakarta: Pustaka al-Husna, 1987) hlm. 34-36
} 
Piagam Madinah beliau mampu menyatukan seluruh rakyat dengan kedaulatan yang berdiri dibawah kekuasaannya. Dalam perkembangan masyarakat Madinah ini jauh melampaui pemikiran dari masyarakat Arab ketika itu. Bahkan mungkin tidak pernah terpikir oleh manusia dimuka bumi ketika itu.

Sejarah mencatat bahwa Rasulullah adalah pemimpin yang tidak hanya mampu membangun kekuatan spiritual pengikutnya tetapi juga mampu membangun karakter sosial antar sesama umatnya. Dengan adanya aturan-aturan yang dibuat dalam perjanjian tersebut terjalin kontak sosial yang baik sesama rakyat Madinah sebelum kaum Yahudi berusaha merusak perjanjian dengan melakukan beberapa tindakan yang sangat jelas mengganggu legitimasi perjanjian tersebut, seperti melakukan fitnah, kerja sama dengan kafir Quraisy demi meruntuhkan eksistensi Nabi di Madinah, dan juga beberapa tindakan yang tentu memerlukan sikap politik yang tegas dari Nabi, hingga dengan sangat terpaksa Rasulullah pada akhirnya mengusir _melakukan pembersihan_ orang-orang Yahudi di Madinah dikarenakan tingkah laku mereka sendiri. Maka dengan segala aspek setelah Piagam Madinah dicetuskan, perlu kiranya melihat sikap politik Nabi di Madinah yang tentu tujuan utamanya ialah membangun masyarakat Madani yang sesuai dengan kehendak Allah Swt.

\subsection{Universalitas Sikap Politik, dan Civil Society}

Matahari Islam pun bersinar di atas langit bersih kota Madinah dan cahayanya mulai memancar luas. Salah satu hasil pertamanya adalah keadaan perang yang mencekam dua kabilah 'Aus dan Khazraj berubah menjadi keadaan damai dan persahabatan. Orang-orang mukmin Madinah berkumpul di sekeliling Nabi dan perlahan-lahan kabilah-kabilah di wilayah Madinah pun memeluk Islam. Undang-undang Allah pun diwahyukan dan kemudian di wujudkan serta dipraktekkan satu persatu. Setiap hari, satu bentuk perilaku jahat tentu dibasmi dan diganti dengan kesalehan dan keadilan. Perlahan-lahan orang-orang mukmin di Mekkah yang dapat banyak gangguan dari orang-orang kafir Mekkah setelah hijrahnya Nabi Muhammad Saw, meninggalkan rumah dan kehidupan mereka lalu 
pindah ke Madinah dan mereka disambut dengan hangat oleh saudara-saudara mereka se-agama disana. ${ }^{34}$

Dalam melihat sikap politik yang menciptakan sikap sosial dengan ciri masyarakat Madani maka perlu mengkaji pendapat Syed Mahmudunnasir mengenai karakter sosial Nabi Muhammad dalam membangun umat. Syed Mahmudunnasir mengatakan bahwa Nabi Muhammad tidak hanya pendiri suatu agama, pencipta suatu bangsa baru, tetapi juga seorang pembaharu (reformer) bagi suatu tatanan sosial yang besar. ${ }^{35}$ Ajaran yang dibawa oleh Muhammad Saw adalah sikap persamaan dalam konteks kemanusiaan, tidak ada yang membedakan manusia kecuali kedekatannya kepada Tuhan (Takwa). Beliau juga memandang sikap keadilan bagi seluruh umat manusia di muka bumi.

Di samping usaha menegakkan persamaan dan keharmonisan sosial, beliau menciptakan kerukunan kembali di antara agama-agama dunia yang berselisih dengan menetapkan kebijakan toleransi beragama. Dia menjelaskan bahwa umat Islam harus percaya kepada semua nabi yang dikirim ke dunia dari waktu ke waktu. Tidak boleh seorang pun menjelekkan agama orang lain. Dan belia pernah bersabda "janganlah kamu sekalian memperlakukan dengan kasar mereka yang percaya kepada tuhan-tuhan selain Allah.” Sesungguhnya, tujuannya untuk menegakkan persaudaraan universal di antara umat manusia sehingga semua manusia dapat hidup secara damai dan harmonis. ${ }^{36}$

Selain itu Nabi Muhammad membangun dan menerapkan aturan politis demi kebaikan umat dan menghilangkan sikap-sikap Jahiliyah yang telah mendarah daging ratusan lamanya di Jazirah Arab. ${ }^{37}$ Nabi Muhammad merupakan seorang sosialis ${ }^{38}$ yang bertujuan menjembatani kesenjangan-kesenjangan antara

${ }^{34}$ Fatah Syukur NC, Sejarah Peradaban Islam, (Jakarta: PT Pustaka Rizki Putra, 2015) hlm. 39

${ }^{35}$ Syed Mahmudunnasir, Islam.., hlm. 119

${ }^{36}$ Ibid., hlm. 120

37 Seperti meminum minuman keras, zina, melecehkan wanita, membunuh anak perempuan, perbudakan, riba, sikap memandang rendah si miskin dan lain sebagainya. Lihat : Syed Mahmudunnasir, Islam.., hlm. 120-121

${ }^{38}$ Kata "sosialis" sebenarnya kurang tepat jika diposisikan untuk sosok Nabi Muhammad karena hanya akan mempersempit karakter beliau yang paripurna, tetapi ini hanya kata yang dikutip oleh Syed Mahmudunnasir demi menggambarkan siap sosial Nabi, bukan berarti beliau adalah seorang sosialis utuh yang menganut paham sosialisme, itu sangat tidak tepat jika disandangkan pada pribadi beliau. Yang dimaksud sosialis disini ialah suatu sifat/karakter dari orang-per-orang, kelompok (komunitas), masyarakat ataupun negara, yang mengedepankan satu 
kaum kaya dan kaum miskin, orang yang berkedudukan tinggi dengan orang yang berkedudukan rendah. Dia membayangkan suatu masyarakat yang tidak mengenal lagi pemerasan oleh kelompok yang satu terhadap kelompok yang lain. Untuk membantu kaum yang miskin dan yang menderita, dan untuk meratakan pembagian kemakmuran, beliau memperkenalkan zakat, sedekah, dan fitrah di dalam masyarakat Islam. Di samping itu beliau mengatur agar status sosial seseorang jangan didasarkan atas kedudukan ekonomi orang itu, tetapi atas dasar sejauh mana ketaatannya kepada Allah dan Rasul-Nya. ${ }^{39}$

\subsection{Visi Politik dan Ekonomi Sebagai Jaminan Stabilitas Sosial}

Aspek politik ini dapat dilihat dalam hal pertahanan dan keamananyang bertujuan untuk menjalin hubungan antar umat beragama yang ditetapkan dalam Piagam Madinah antara lain pada pasal 24, 37, 38, dan 44, yang secara umum diberlakukan kepada seluruh warga Madinah. Pasal-pasal tersebut berbunyi:

"Sesungguhnya kaum Yahudi bersama-sama orang mukmin bekerja sama dalam menanggung pembiayaan selama mereka mengadakan peperangan bersama" (pasal 24), "Sesungguhnya kaum Yahudi wajib menanggung nafkah mereka dan orang-orang mukmin menanggung nafkah mereka sendiri. Tapi,di antara mereka harus ada kerja sama atau tolong menolong dalam menghadapi orang yang menyerang warga sahifah ini, mereka saling memberi saran dan nasihat dan berbuat kebaikan, bukan perbuatan dosa" (pasal 37), "Sesungguhnya kaum Yahudi bersama-sama orang mukmin bekerja sama menanggungpembiayaan selama mereka menghadapi peperangan mereka" (pasal 38), dan "Sesungguhnya diantara mereka harus ada kerja sama, tolong menolong untuk menghadapi orang yang menyerang kota Yasrib". (pasal 44)"

Bunyi pasal diatas sudah sangat mampu untuk membuat pertahanan yang kokoh bagi kota Madinah. Tentu Rasulullah sebagai "panglima” utama dalam

rasa kebersamaan, yang mementingkan kehidupan yang baik untuk orang lain, untuk komunitas yang lebih besar, yang mengedepankan kepentingan bersama lebih baik atau paling tidak sama baik dengan dirinya, dan yang paling penting: tidak mengutamakan ego/kepentingan diri sendiri daripada orang lain/komunitas yang lebih banyak.

${ }^{39}$ Syed Mahmudunnasir, Islam.., hlm. 122 
mempertahankan negeri Madinah tidak luput menjadikan Madinah kota yang aman dari gangguan luar terutama gangguan dari kaum kafir musyrik yang memendam kebencian yang mendalam kepada Rasulullah dan para pengikutnya. Tentu jika menilik aspek politik ini, ada hal yang harus menjadi pertanyaan utama, jika Rasulullah tidak membuat peraturan perundang-undangan baku yang berbunyi seperti diatas apakah Madinah bisa bertahan? Tentu tidak. Walaupun legitimasi kenabian yang dimiliki oleh Rasul, tidak semerta beliau berpangku tangan kepada Tuhan untuk menjaganya dari gangguan luar, tentu aspek sunnatullah $^{40}$ sangat berlaku pada kepemimpinan Rasul. Ini juga menjadi social control bagi Nabi untuk melihat mana dari rakyatnya yang benar-benar loyal dan komitmen dengan perjanjian yang sudah disepakati bersama.

Untuk membangun perekonomian dan perbendaharaan negara, diterapkan adanya kewajiban zakat (bagi muslim) dan jizyah atau pajak (bagi non muslim), Juga dianjurkan infaq, sadaqah dan wakaf. Nabi juga mengajarkan system ekonomi laba jual beli, musyarakah, mudharabah dan sebagainya. Prinsip-prinsip tersebut kini telah melahirkan sistem ekonomi Islam dan perbankan Syari'ah. Melarang secara tegas mengambil hak orang lain baik muslim ataupun non muslim. Perbendaharaan (keuangan) negara selain untuk pembiayaan tegaknya negara madinah, juga menjadi jaminan sosial bagi kaum dhuafa. Menurut beberapa penulis sejarah bahwa banyak wilayah mayoritas non muslim memilih bergabung dengan pemerintahan kaum muslimin karena penerapan pajak (jizyah) yang ringan dibandingkan dengan penerapan pajak pada kekuasaan Romawi dan Persia. Hal ini mulai terjadi di masa pemerintahan khulafa al Rasyidin.

Dibidang sosial seperti yang telah dijelaskan sebelumnya bahwa Rasulullah membawa suatu perubahan yang sangat penting dan sangat revolusioner bagi Madinah dan Arabia pada umumnya. Nabi berhasil menyatukan suku-suku Madinah yang heterogen ((yaitu suku Aus dan Khazraj, dan kaum Anshar dan kaum Muhajirin) ke dalam suatu kesatuan politik yang padu.

40 Sebab-akibat. Jika Rasul tidak mempersiapkan pertahanan yang matang pastilah akibatnya Rasul dan pengikutnya sangat mudah diserang. Dan membuat eksistensi kenabian Rasul dan juga umatnya terganggu oleh serangan-serangan tersebut. Walau dalam kenyataannya selama di Madinah Rasul dan Umat Islam berjuang sendiri untuk mempertahankan Madinah, seperti terlihat pada perang-perang yang terjadi, bahkan Yahudi ikut membuat makar bersama kafir Mekkah untuk menghancurkan eksistensi Nabi di Madinah 
Rasulullah mengakui kebebasan perseorangan dan umum, menjamin keamanan perseorangan dan milik rakyat, serta membantu tumbuhnya kebajikan-kebajikan warga negara. Kepemimpinan Rasulullah Saw bernapaskan semangat toleransi keagamaan umat Islam, menetapkan hak-hak dan kewajiban umat Islam terhadap satu sama lain dan terhadap orang-orang Yahudi. Hal ini memberikan pukulan maut kepada adt istiadat kuno bangsa Arab. Ia menyorotkan cahaya yang terang pada kenegarawanan serta toleransi keagamaan Nabi Muhammad terhadap kaumkaum minoritas dan kaum-kaum non-Islam. ${ }^{41}$

Berbicara mengenai aspek sosial tentunya tidak terlepas dari fakta sejarah mengenai bagaimana kepengelolaan Nabi terhadap rakyatnya, baik kepada umat Islam maupun kepada noo-Islam. Hal ini selalu menjadi suatu yang menarik, dikarenakan masyarakat Madinah adalah masyarakat yang heterogen, hingga bisa dikatakan tersimpullah pluralitas dalam social ethics (etika sosial) yang dijalankan Nabi dalam kepemimpinannya.

Menurut Yusno Abdullah Otta dalam jurnalnya yang berjudul Madinah dan Pluralisme Sosial (Studi atas Kepemimpinan Rasulullah), bahwa aspek sosial politik masyarakat Madinah sangat beragam dan pluralistik, ini karena tidak adanya satu penguasa yang dapat menyatukan mereka dalam satu pimpinan. Keadaan ini berbeda dengan di Mekkah, pemegang kekuasaan politik dan ekonomi berada di tangan aritokrasi Quraisy, yang merupakan suku yang paling dominan di banding suku lain. Konflik yang berkepanjangan antara suku Aus dan Khazraj di Madinah, menjadikan mereka tidak pernah bersatu, walaupun mereka satu keyakinan dan kepercayaan. Kemenangan suku 'Aus atas Khazraj dalam perang Bu'ats, menunjukkan betapa lemahnya masyarakat Madînah dalam menggalang persatuan karena krisis kepemimpinan. ${ }^{42}$

Struktur penduduk Madînah pascahijrah tentu saja lebih pluralistik ketimbang prahijrah. Mereka terdiri atas bangsa Arab Madinah yang telah masuk Islam di sebut kaum Anshar, orangorang Mekkah yang hijrah di sebut kaum Muhajirin, kelompok penduduk Madinah yang masih menganut paham paganis, golongan Yahudi yang terdiri dari berbagai suku, baik orang Arab maupun bangsa

\footnotetext{
${ }^{41}$ Syed Mahmudunnasir, Islam.., hlm. 133

42 Yusno Abdullah Otta, Madinah dan Pluralisme Sosial (Studi atas Kepemimpinan Rasulullah), Jurnal Al-Syir'ah Vol. 8, No. 2, Desember 2010, hlm. 486
} 
Yahudi sendiri, kaum munafik dan musyrik Madînah, dan kaum minoritas penganut agama Kristen. ${ }^{43}$ Gambaran pluralistik masyarakat Madînah terdiri dari, suku, etnis, agama, asal daerah, ekonomi, agama dan keyakinan serta adat istiadat dan budaya. Keadaan ini menuntut mereka untuk bertindak sendiri dalam mewujudkan kepentingan tiap kelompoknya dalam mencapai kemajuan menurut prinsip dan filsafat hidup yang diyakininya serta budaya yang mengitarinya. Di tinjau dari segi kebangsaan, penduduk Madînah terdiri dari dua bangsa yang berbeda, yaitu bangsa Arab dan bangsa Yahudi. Dari segi agama dan keyakinan, mereka ada yang masih memegang teguh keyakinan nenek moyang mereka, paganisme, ada kolompok Islam, Anshar dan Muhajirin, Yahudi dan kelompok minoritas Kristen di pinggiran kota. Dari segi ekonomi, bangsa Yahudi yang memegang hampir semua sektor perekonomian, terutama pertanian dan industri, dan mereka pula yang menguasai pasar. Mereka adalah kaum pendatang yang menjadi tuan tanah dan menguasai modal, sementara bangsa Arab hanya menjadi the second class economic, pelayan di negeri sendiri. Dari segi struktur sosial dan kultur, mereka memiliki prejudice kesukuan (tribal prejudice), tapi berbeda dalam adat istiadat. $^{44}$

Dari elemen dan instrumen masyakat diatas tentunya mampu menimbulkan konflik antara mereka. Karena, komunitas masyarakat yang terdiri dari bermacam golongan memiliki perbedaan kepentingan dalam berbegai bidang; sosial, ekonomi, politik, dan agama yang cenderung saling mengeliminasi dan mencari celah untuk saling menyalahkan satu dengan lainnya, daripada mencari persamaan di antara mereka. ${ }^{45}$ Berbagai kelompok agama dan keyakinan yang berdomisili di Madînah dan sekitarnya juga disinggung dalam Alquran. ${ }^{46}$ Maka dari itu Rasul datang memperbaiki masyarakat Madinah baik secara sosial, ekonomi ataupun budaya.

\footnotetext{
${ }^{43}$ J. suyuthi Pulungan, Prinsip-prinsip Pemerintah dalam Piagam Madinah: Ditinjau dari Pandangan Al-Quran, (Jakarta: RajaGrafindo, 1996), hlm. 57

${ }^{44}$ Yusno Abdullah Otta, Madinah.., hlm. 487

45 Soerjono Soekamto, Sosiologi, Suatu Pengantar, (Jakarta: Rajawali Press, 1982), hlm.94.

${ }^{46}$ QS. Al-Maidah (5) : 82; at-Taubah (9): 100, 101, 117. Ayat-ayat tersebut merupakan bukti bahwa Alquran juga dapat dijadikan sumber referensi sejarah, karena informasi yang diberikan terbukti dalam realitas historis. Lihat : Yusno Abdullah Otta, Madinah.., hlm. 488
} 
Suatu masyarakat yang memiliki tatanan yang pluralis dan heterogen sebenarnya tersimpan kekuatan, yang dioptimalkan akan memberikan dampak positif bagi komunitas tersebut. Sejak prahijrah, struktur masyarakat Madinah telah pluralis dan heterogen. Terlebih setelah kedatangan kaum Muslimin yang berhijrah dari Mekkah. Struktur masyarakat seperti ini tidak ditemukan pada komunitas Mekkah. Keadaan ini, tentu saja, menguntungkan dari segi sosial ekonomi dan politik, karena pluralitas dapat memacu semangat kompetisi ke arah kebaikan bila diakomodasi dengan baik. Namun bisa menjadi bumerang bila tidak dikelola dengan baik. Dan Nabi Muhammad, sebagai pemimpin Bangsa Madinah, mampu menyatukan berbagai komponen masyarakat tersebut dalam suatu wadah yang disebut jamaah. Tantangan yang ada dijadikan peluang oleh Muhammad Saw, dan sekaligus sebagai pembuktian akan kebenaran ajaran yang dibawanya. ${ }^{47}$

Langkah awal yang dilakukan Muhammad Saw dari segi ekonmi di Madinah ialah memenuhi kebutuhan orang-orang yang bersertanya dalam berhijrah, Muhajirin. Mereka adalah para saudagar dan pedagang yang meninggalkan dagangan dan hartanya di Mekkah demi untuk berhijrah bersamannya. Untuk menangani ini, Muhammad Saw meminta bantuan dan kebaikan kaum Anshar, penduduk Madinah, untuk membantu saudara-saudara mereka dari Mekkah yang kehilangan pekerjaan. Seruan muhammad ini dijawab oleh penduduk Madinah secara spontanitas. Ada di antara kaum Anshar yang menawarkan kepada penduduk Mekkah tanah garapan untuk dijadikan perkebunan. $^{48}$

Nabi Muhammad Saw menanamkan rasa cinta kasih dalam lintas komunitas masyarakat Madinah terutama Muhajirin dan Anshar. Membangun dan menyatukan kedua kelompok ini atas dasar cinta. Mendobrak kekokohan egois yang telah lama bersarang dalam hati pribadi masing-masing kelompok dan menanamkan suatu kepercayaan bahwa orangorang Mukmin yang benar adalah mereka yang hidup dalam masyarakat yang terbebas dari belenggu egoisme dan saling mengeksploitasi sesama mereka. Mukmin yang baik adalah orang yang

${ }^{47}$ G.E. Van Grunebaum, Classical Islam, A History 600 - 1258, trans., Katherin Watson, (Chicago: Aldine Publishing Company, 1970), hlm. 32.

${ }_{48}$ Ahmad Ibrahim Syarif, Daulat al-Rasul fî al-Maînnah, Kuwait: Dar al-Bayan, 1392/1972, hlm. 86. 
merdeka secara pikiran maupun keyakinan. Yang selalu lapang dada dan menolong satu dengan lainnya dalam menghadapi setiap permasalahan hidup. ${ }^{49}$ Komunitas yang dibangun Muhammad Saw adalah kehidupan yang dilandasi saling menghormati: orang kaya tidak meremehkan orang miskin, pemimpin dan orang kuat dilarang mengeksploitasi orang lemah dan miskin.

Membangun sarana dan prasarana yang dapat dijadikan tempat untuk memperat silaturahmi antara Muhajirin dan Anshar, dan tempat untuk mempelajari Islam. Muhammad Saw mendirikan mesjid sebagai sentral kegiatan dakwah dan sosial. Mesjid adalah pusat kendali semua kegiatan masyarakat Madinah. Di mesjid pula, Muhammad Saw mengakomodasi segala perbedaan yang terjadi antara Muhajirin dan Anshar, bangsa Arab dan Yahudi dan antar orang Yahudi sendiri, yang mayoritas jumlahnya dibanding Muhajirin dan Anshar. Situasi ini, tentu saja membutuhkan undangundang dan peraturan yang mengatur dan mengikat setiap kelompok yang ada. Bila, pertama kali ke Madînah, Muhammad Saw tidak lebih hanya sebagai pemimpin agama (Nabi), maka, setelah situasi dan kondisi Madinah bisa dikendalikan. Nabi Muhammad mulai mengeluarkan dan menetapkan undang-undang yang berlaku bagi semua penduduk Madinah tanpa kecuali. Buah dari semua usaha ini mulai nampak ketika kaum Muslimin memenangkan perang Badar. Ketika itu, bangsa Yahudi di Madinah mulai merasa risau dengan keadaan ini. Kemenangan kaum Muslimin dalam Perang Badar ini menjadi titik awal Nabi Muhammad dalam memegang kendali atas kota Madinah. ${ }^{50}$

Langkah yang diambil Muhammad Saw pasca-hijrahnya ke Madinah sungguh strategis, dan ini merupakan politik dasar dari terbentuknya negara Madinah, dengan Muhammad Saw selaku kepala negara sekaligus kepala pemerintahan. Pemerintahan Nabi Muhammad dibangun atas dasar keikhlasan dalam rangka menyebarkan risalah Allah SWT. Pembentukan negara ini, bukan berorientasi pada kekuasaan dan eksploitasi manusia, tapi, justru sebaliknya, untuk mendobrak dan mengikis habis akar warisan dan kebiasaan yang sudah

${ }^{49}$ Akram Dhiyauddin Umari, Masyarakat Madani: Tinjauan Historis Kehidupan Zaman Nabi, terj. Mun'im A Sirry, (Jakarta :Gema Insani Press , 1999) hlm. 78-79.

50 W. Montgomery Watt, Muhammad, Prophet And Statesman, (London: Oxford University Press, 1969). hlm. 96 
berjalan lama di kalangan masyarakat pada masa itu berupa supremasi manusia atas manusia. Dan inilah yang menjadikan Muhammad Saw begitu dikenang dan dihormati baik oleh kawan maupun lawan-lawannya. Serta ini pula yang menjadikannya sebagai tokoh berpengaruh dalam urutan pertama, di banding tokoh dunia lainnya, seperti Napoleon Bonaparte atau Julius Cesar, dan di banding Nabi dan raja lainnya, seperti Isa, Daud dan Musa serta Sulaiman. ${ }^{51}$

\subsection{Beberapa Rintangan dalam Membangun Masyarakat Madani}

Dalam menciptakan masyarakat yang sejahtera serta adil dan makmur yang sesuai dengan aturan dari Allah Swt, tentulah tidak selalu berjalan dengan lurus dan lancar. Pastinya terdapat hambatan dan rintangan yang dihadapi oleh Nabi Muhammad Saw. Jika ketika di Mekkah Rasul mendapatkan kecaman dan tindakan kekejaman dari keluarganya sendirinya maka di Madinah Rasulullah mendapatkan rintangan dari kaum Yahudi dan juga kaum Munafik yang tidak pernah senang dengan eksistensi Nabi Muhammad Saw. Walaupun secara eksternal Rasulullah tetap berhadapan dengan kaum kafir Mekkah demi mempertahankan Madinah dari serangan-serangan yang dilakukan. Setiap tindakan pengkhianatan atau penyerangan, Rasulullah Saw dan umat Islam hanya melakukan self Defense. Dikarenakan Rasulullah taat pada perdamaian dan tidak menyukai pertempuran, pertempuran hanya dilakukan jika umat Islam mempertahankan diri demi menjaga ajaran Islam tidak dirusak oleh kaum kafir Quraisy dan kaum munafik.

Ketika Rasulullah menjalankan dakwah atau menjalankan sistem pemerintahannya Rasulullah Saw mendapat sambutan beragam, ada yang menerima kemudian masuk Islam dan ada pula yang menolak secara diam-diam, misalnya, orang-orang Yahudi yang tidak senang atas kehadiran nabi dan umat Islam. penolakan ini mereka lakukan secara diam-diam dan tidak berani berterus terang untuk menantang nabi dan umat Islam yang mayoritas tersebut. Kedengkian orang-orang Yahudi semakin menjadi-jadi, sewaktu mereka menyaksikan sendiri perkembangan pesat agama yang dibawa nabi, seakan-akan

${ }^{51}$ Lihat, Michael Hart, Seratus Tokoh yang Paling Berpengaruh dalam Sejarah, (Jakarta: Pustaka Jaya, 1982). 
jalan untuk mencapai kemenangan telah terhampar datar. ${ }^{52}$ Apalagi sekutu mereka (suku Aus dan Khazraj) setelah memeluk Islam, sudah tak membutuhkan mereka lagi, karena telah mendapat pimpinan yang ideal yakni Muhammad saw.

Akhirnya Yahudi Madinah menggalang koalisi dengan kafir Quraisy Mekah, untuk menghancurkan kekuatan umat Islam. bahkan peperangan terjadi antara kaum muslim Madinah dengan musyrik quraisy Mekah. Perang pertama yang sangat menentukan masa depan negara Islam ini adalah perang Badar pada tanggal 17 Ramadhan tahun ke 2 Hijriah, nabi bersama 305 orang muslim bergerak keluar kota membawa perlengkapan yang sederhana. Di daerah Badar, kurang lebih 120 kilometer dari Madinah, pasukan nabi bertemu dengan pasukan quraisy yang berjumlah sekitar 900 sampai 1000 orang. Nabi sendiri yang memegang komando. Dalam perang ini kaum muslimin keluar sebagai pemenang. ${ }^{53}$

Dalam beberapa tahun berikutnya, pihak Quraisy Mekah menyerang pihak Nabi Muhammad Saw di Madinah. Sehingga terjadi lagi peperangan, yakni perang Uhud $(625 \mathrm{H})$ dan kemudian disusul perang Khandak $(627 \mathrm{H})$. Dalam perang Uhud, pihak Muhammad menderita kekalahan, sedang dalam perang Khandaq pihak Nabi Muhammad Saw berhasil menghancurkan dan membuat kecewa pihak Mekah, pihak Nabi Muhammad Saw diuntungkan dalam kedua peperangan tersebut. Beliau berhasil bertahan dari serangan yang dilancarkan pihak Mekah, dan bahkan pada setiap kesempatan menyusun rencana pengusiran atau penghukuman terhadap sisa-sisa klan Yahudi, merampas kekayaan mereka dan memperluas pengaruh dirinya terhadap suku-suku di padang pasir di Arabia.54

Tentang pengingkaran orang-orang Yahudi ini disebutkan dalam surah alBaqarah ayat 89. Mereka memang pernah mengikat perjanjian dengan kaum muslimin, akan tetapi, tampaknya mereka tidak sungguh-sungguh menyetujui perjanjian itu dan tidak dilandasi oleh hati yang jujur. Pada mulanya mereka patuhi perjanjian tersebut, karena mereka mampu menghadapi kekuatan kafir

\footnotetext{
${ }^{52}$ A.Syalabi, Sejarah dan Kebudayaan Islam I, (Jakarta: Pustaka al-Husna, 2003), hlm. 115

${ }^{53}$ Badri Yatim, Sejarah Peradaban Islam, (Jakarta: Rajawali Press, 1993) hlm. 27

${ }^{54}$ Ira M. Lapidus, A History of Islamic Sicieties, diterjemahkan oleh Ghufron A. Mas seadi, dengan judul "Sejarah Sosial Ummat Islam", (Jakarta: Raja Grafindo Persada, 1999) hlm. 47
} 
Quraisy. Mereka terkejut ketika Rasulullah dan para pengikutnya berhasil memporak-porandakan tentara Quraisy dalam perang Badar. ${ }^{55}$

Kedengkian orang-orang Yahudi makin meningkat ketika mereka menyaksikan sendiri betapa pesatnya agama yang dibawa oleh Nabi Muhammad Saw itu tersiar di Madinah. Belum pernah ada satu pun ajaran yang berkembang begitu cepat seperti perkembangan Islam pasca hijrah. Mereka menempuh berbagai cara untuk menghentikan perkembangan Islam itu. Berbagai cara mereka lakukan untuk menghancurkan dan merusak tatanan kedamaian yang telah dibangun oleh Rasulullah. ${ }^{56}$ Hingga puncaknya mereka membatalkan perjanjian secara sepihak. Bani Qainuqa ${ }^{57}$ adalah kelompok pertama yang merusak perjanjian tersebut. Pelanggaran yang mereka lakukan adalah melakukan pelecehan terhadap perempuan muslimat di pasar Bani Qainuqa yang menimbulkan konflik dan korban jiwa antar kelompok yaitu antara kaum Yahudi dan kaum muslimin. ${ }^{58}$ Karena pelangaran tersebut, mereka dikepung selama 15 hari, harta dan senjatanya disita dan mereka diusir dari Madinah. Pengusiran itu terjadi pada akhir tahun kedua sesudah hijrah, tepatnya setelah terjadi perang Badar. $^{59}$ Lalu selanjutnya yang membuat ulah Bani Nadhir, yang setahun kemudian berusaha membunuh Rasulullah Saw, ${ }^{60}$ atas pengkhianatan itu, perkampungan mereka dikepung selama 16 hari, dan mereka diusir dari Madinah. Rasulullah mengizinkan mereka membawa harta benda sebanyak yang bisa

${ }^{55}$ Umar Farrukh, al-A'rab wa al-Islam fi al-Haudl al-Syarqiy min al-Bahr al-Abyad alMutawassith, (Beirut : Dar al-Kutub, 1996) hlm 49. Dalam Siti Maryam Dkk, Sejarah.., hlm. 33

56 Mula-mula dengan cara berdebat untuk menimbulkan keraguan dikalangan kaum muslimin atas ajaran Rasulullah, agar mereka meninggalkan agamanya. Akan tetapi upaya ini gagal, bahkan tidak mampu menghalangi mereka yang hendak masuk Islam. Tipu daya mereka terbongkar dan kedudukan Rasulullah semakin kuat, karena beliau mampu membuktikan kebenaran risalahnya. Ulah mereka itu disebutkan dalam surah Al-Baqarah ayat 109. Setelah cara pertama gagal, orang-orang Yahudi melakukan keonaran, menghasut dan memprovokasi penduduk Madinah. Lihat : Siti Maryam Dkk, Sejarah.., hlm. 34

57 Setidaknya ada tiga golongan Yahudi yang ada di Madinah yang mendominasi di Madinah, yaitu Bani Qainuqa, Bani Nadhir dan Bani Quraidhah. Ketiga inilah yang kelak akan berusaha merusak perjanjian dan mengganggu eksistensi kedamaian di Madinah

58 Al-Hamid Al-Husaini, Membangun Peradaban Sejarah Muhammad SAW Sejak Sebelum diutus Menjadi Nabi (Bandung: Pustaka Hidayah, 2000) hlm. 509

${ }^{59}$ Siti Maryam Dkk, Sejarah.., hlm. 34

60 Kira-kira setahun kemudian, Amr ibn Jahasy dari Bani Nadhir mencoba hendak membunuh Rasulullah dengan menjatuhkan batu dari atas tembok tempat beliau dan para sahabatnya istirahat. Pada saat itu beliau ditemani oleh Abu Bakar, Umar, dan Ali sedang berkunjung diperkampungan mereka. Allah memerintahkan beliau untuk segera meninggalkan tempat itu, hingga beliau selamat dari perbuatan keji mereka. 
dibawa seekor unta, tapi tidak seorang diizinkan membawa baju besi. Pengusiran itu terjadi pada bulan Rabiul Awwal tahun keempat hijriyah. ${ }^{61}$

Pada saat terjadi Perang Ahzab atau disebut juga Perang Khandaq kaum Yahudi Bani Quraizah melakukan pengkhianatan dengan membuka daerah pemukiman yang tidak dilintasi parit. Mereka melakukan itu sebagai upaya kerjasama dengan musuh, sehingga pasukan musyrikin dapat masuk ke dalam kota untuk menyerang tempat kediaman Nabi, namun upaya tersebut dapat digagalkan oleh kaum muslimin. ${ }^{62}$

Kebijakan Nabi terhadap kaum Yahudi Madinah merupakan upaya tegas dari seorang pemimpin negara terhadap bentuk kriminalitas yang dilakukan oleh penduduknya berupa pelanggaran terhadap perjanjian yang telah disepakati bersama. Pelanggaran kaum Yahudi mengakibatkan keresahan sosial yaitu ketidaknyamanan bagi kaum muslimin yang sering dihina dan dilecehkan yang pada akhirnya berakibat pada pertumpahan darah dan konflik antar kelompok sehingga memecah belah hubungan sosial dan rasa persatuan penduduk Madinah. Pelanggaran dan pengkhianatan kaum Yahudi tersebut, juga berdampak pada aspek politik Madinah karena pertikaian yang terjadi melemahkan kesatuan masyarakat Madinah sebagai sebuah negara yang baru dibangun.

Kebijakan yang dikeluarkan oleh Nabi merupakan upaya politik yang bertujuan pada ranah sosial yaitu memberi rasa aman kepada penduduknya, dengan tujuan akhir menyejahterakan masyarakat Madinah. Dalam melaksanakan kebijakan tersebut, Nabi harus menetapkan hukuman bagi mereka yang bersalah sebagaimana yang terdapat pada Piagam Madinah yang telah disepakati bersama, meskipun dalam realisasinya Nabi juga tetap memperhatikan etika-etika kemanusiaan.

Selain Yahudi, Nabi Muhammad Saw juga menghadapi kaum munafik yang secara tidak langsung merongrong kedamaian di Madinah. Keberadaan orang-orang munafik tidak bisa diabaikan begitu saja sebagai ancaman yang sangat membahayakan. Pengaruh mereka memang tidak begitu besar, namun apabila dibiarkan bisa menimbulkan malapetaka yang merugikan perjuangan umat

\footnotetext{
${ }^{61}$ Siti Maryam Dkk, Sejarah.., hlm. 34

${ }^{62}$ Al-Hamid Al-Husaini, Membangun.., hlm. 574
} 
Islam. Sekalipun mereka mengaku beriman kepada Rasulullah Saw, namum seringkali mereka menghalang-halangi orang lain masuk Islam. Ketika Rasulullah Saw bersiap untuk menghadapi perang Uhud, kaum munafik keluar dari barisan yang dipersiapkan itu atas hasutan Abdullah bin Ubay, pemimpin mereka. Mereka juga mengadakan hubungan baik dengan kaum Yahudi dan pernah menjanjikan bantuan bagi Bani Quraidhah sewaktu disebut terakhir ini mengkhianati umat muslim. Tentu masih banyak lagi perbuatan mereka yang merugikan kaum muslimin dan eksistensi kepemimpinan Nabi Muhammad dalam menciptakan perdamaian. Terhadap orang-orang munafik ini Rasulullah bersikap lunak sambil berusaha menyadarkan mereka supaya beriman secara benar. Usaha Rasulullah tidak sia-sia, ternyata kelompok orang munafik ini tidak ditemukan lagi setelah Abdullah bin Ubay meninggal dunia. ${ }^{63}$

Lalu, selain mendapatkan gangguan dari internal kota Madinah, Rasulullah Saw juga terus mendapatkan gangguan dari eksternal Madinah, yaitu dari kaum kafir Quraisy yang tidak pernah senang dengan perkembangan umat Islam di Madinah. Maka seperti yang telah diketahui mereka selalu berusaha melancarkan serangan, pecahlah perang Badar untuk pertama kali yang membuat luluh lantak kekuatan dari kaum Quraisy dan sekaligus menunjukkan legitimasi dan eksistensi kekuatan Nabi Muhammad Saw. Lalu perang selanjutnya yaitu Perang Uhud yang membuat umat Islam terpukul karena kekalahan telak yang disebabkan salah satu pasukan yang tidak mematuhi Rasulullah.

Juga peperangan selanjutnya seperti Perang Ahzab, Perang Mut'ah dan penaklukkan-penaklukkan lainnya. Inti peperangan yang dilakukan oleh Rasulullah Saw adalah demi terbentuknya masyarakat yang adil dan makmur yang sesuai dengan ridha Allah Swt. Konsep masyarakat yang dibangun oleh Rasulullah adalah bertumpu pada kedamaian dan saling menghormati. Dalam sejarah kepemimpinan Rasulullah Saw masyarakat merasa aman, dan tentram baik muslim atau non-muslim. Rasulullah tidak membedakan dalam menegakkan keadilan bagi si muslim atau non-muslim. Hingga Rasulullah Saw wafat, beliau telah meninggalkan bekas kedamaian dan konsep keteraturan yang baku dan fleksibel. Hanya dua hukum yang ditinggalkan oleh Rasulullah yaitu al-quran dan

\footnotetext{
${ }^{63}$ Siti Maryam Dkk, Sejarah.., hlm. 35
} 
sunnahnya yang bisa diikuti oleh setiap umatnya. Jika kedua ini telah menjadi panduan utama bagi umatnya dimasa yang akan datang, maka tentulah kedamaian paripurna yang diharapkan oleh segenap manusia akan terwujud.

\section{PENUTUP}

\subsection{KESIMPULAN}

Rasulullah Saw terbukti dalam sejarah telah berhasil menciptakan kesejahteraan yang sangat mengagumkan. Bahkan belum pernah ada tokoh seperti beliau dalam sejarah umat manusia. Beliau mampu membangun social integrity yang tinggi bagi semua umatnya. Umatnya yang terdiri dari budak dan masyarakat yang tidak memiliki kedudukan dimasyarakat mampu ditinggikan derajatnya oleh Rasulullah. Karena ajaran yang dibawa Rasulullah adalah kesamaan dimata manusia, yang membedakan hanyalah takwanya.

Pembangunan karakter sosial yang pertama kali dilakukan oleh Rasulullah Saw adalah dengan menyatukan atau mempersaudarakan kaum Muhajirin dengan kaum Anshar. Dalam hal ini Rasulullaa Saw menyelematkan perekonomian masyarakat Mekkah yang tidak membawa apapun dari Mekkah ke Madinah, dengan mempersatukan mereka, maka masyarakat Mekkah bisa terbantu oleh Kaum Madinah (Anshar) dalam berdagang ataupun berpenghasilan.

Selain itu Rasulullah Saw juga menyatukan seluruh masyarakat di Madinah dengan membentuk sebuah perjanjian yang disebut Piagam Madinah. Bisa dikatakan Piagam Madinah adalah konstitusi negara pertama yang pernah ada di dunia. Dengan adanya Piagam Madinah, Rasulullah telah menyatukan suku Aus, Khazraj, Yahudi, kaum musyrik (yang belum memeluk Islam) dan sebagian kaum Nasrani. Disinilah Rasulullah menekankan persamaan, kewajiban, tanggung jawab sosial, toleransi, dan juga pertahanan negara. Piagam Madinah menjadi sebuah hukum monumental yang telah menjadi legal standing bagi Rasulullah untuk menjadikan Madinah terjaga dari pihak-pihak luar yang ingin merusak eksistensi perdamaian yang ada di kota Madinah.

Di Madinah Rasulullah leluasa dalam menyebarkan ajaran-ajaran universal bagi masyarakatnya, seperti menghilangkan perbudakan, menghormati kaum wanita, berbuat baik pada tetangga, hidup bertoleransi, tidak berzina, mencuri, memfitnah, berlaku curang, korupsi, Rasulullah juga menyamakan 
antara si miskin dan si kaya, dan kesamaan dalam hukum. Karena konsep yang selalu diajarkan Rasulullah adalah setiap manusia sama dan tidak ada yang membedakan kecuali nilai ketakwaannya kepada Tuhan yang Maha Esa.

Tatanan masyarakat Madani mendapatkan gangguan baik secara internal di dalam Madinah maupun eksternal. Dari internal sendiri kebijakan Rasulullah mendapatkan gangguan dari kaum Yahudi dan kaum munafik, hingga dengan sangat terpaksa Rasulullah harus mengusir kaum Yahudi dari Madinah demi tetap terjaganya suasana yang kondusif. Pada kaum munafik Rasulullah terus mendakwahkan mereka hingga akhirnya mereka mau menerima Islam dengan lurus kembali. Dari eksternal Muhammad Saw mendapat gangguan dari kafir Quraisy yang telah menaruh dendam sejak lama dengan eksistensi umat Islam, maka penyerangan demi penyerangan dilakukan oleh mereka tetapi Rasulullah berhasil menguatkan masyarakat Madinah hingga serangan-serangan tersebut mampu dilumpuhkan oleh Rasul.

Keberhasilan perkembangan masyarakat di bawah kepemimpinan Rasulullah Saw menjadi hal yang sangatlah teruji. Rasul bukan hanya seorang Nabi, tapi beliau adalah politikus, negarawan, pemimpin, kepala negara, administrator, konseptor juga guru bagi kaum dan masyarakatnya, tidak salah beliau telah berhasil membangun peradaban yang diikuti oleh kaumnya kelak.

\section{DAFTAR PUSTAKA}

Al-Faruqi, Ismail Raji', 1998, Tauhid: Its Implications for Thought and Life, terj. Rahmani Astuti, Bandung: Pustaka

Al-Husaini, Al-Hamid, 2000, Membangun Peradaban Sejarah Muhammad SAW Sejak Sebelum diutus Menjadi Nabi, Bandung: Pustaka Hidayah

Ali, K., 2003, Sejarah Islam (Tarikh Pramodern), Jakarta : PT RajaGrafindo Persada.

Arnold, T. W., 1979, The Preiching of Islam, Lahore: Ashraf Printing Press

Azhary, Muhammad Thahir, 1992, Negara Hukum, Cet. I., Jakarta: Bulan Bintang

Bellah, Robert N., 2000, Beyond Belief, cet. I, Jakarta: Paramadina 
Dalizar, 1987, Konsep Al-Quran Tentang Hak Asasi Manusia, Jakarta: Pustaka alHusna.

Grunebaum, G.E. Van, 1970, Classical Islam, A History 600 - 1258, trans., Katherin Watson, Chicago: Aldine Publishing Company

Haikal, Muhammad Husen, 2000, Sejarah Hidup Muhammad, Jakarta: PT.Pustaka Litera Antar Nusa

Hart, Michael, 1982, Seratus Tokoh yang Paling Berpengaruh dalam Sejarah, Jakarta: Pustaka Jaya

Hitti, Philip K., 2008, History of the Arab, Jakarta: Serambi, cet. I

Karya, Soekarna dkk, 1996, Ensiklopedi Mini Sejarah dan Kebudayaan Islam, Jakarta: Logos

Lapidus, Ira M., 1999, A History of Islamic Sicieties, diterjemahkan oleh Ghufron A. Mas"eadi, dengan judul "Sejarah Sosial Ummat Islam", Jakarta: Raja Grafindo Persada

Mahmudunnasir, Syed, 1988, Islam dan Konsepsi Sejarahnya, Bandung : CV Rosda.

Maryam, Siti Dkk, 2004, Sejarah Peradaban Islam, Dari Masa Klasik Hingga Modern, Yogyakarta: LESFI

Nasution, Harun, 1985, Islam di Tinjau dari berbagai Aspek, Jilid.I. Jakarta: UI Press, 1985

NC, Fatah Syukur, 2015, Sejarah Peradaban Islam, Jakarta: PT Pustaka Rizki Putra

Otta, Yusno Abdullah, Madinah dan Pluralisme Sosial (Studi atas Kepemimpinan Rasulullah), Jurnal Al-Syir'ah Vol. 8, No. 2, Desember 2010.

Soekamto, Soerjono, 1982, Sosiologi, Suatu Pengantar, Jakarta: Rajawali Press

Sukardja, Ahmad, 1995, Piagam Madinah dan UUD 1945, Jakarta: UI Press 
Suyuti, J., 1995, Prinsip-Prinsip Pemerintah dalam Piagam Madinah Ditinjau dari Pandangan al-Qur'an, Raja Grafindo Persada: Jakarta

Syalabi, A., 2003, Sejarah dan Kebudayaan Islam I, Jakarta: Pustaka al-Husna, 2003

Syarif, Ahmad Ibrahim, Daulat al-Rasul fì al-Maî̀nah, Kuwait: Dar al-Bayan, $1392 / 1972$

Syazali, Munawir, 1990, Islam dan Tata Negara, Jakarta: UI Press

Umari, Akram Dhiyauddin, 1999, Masyarakat Madani: Tinjauan Historis Kehidupan Zaman Nabi, terj. Mun'im A Sirry, Jakarta :Gema Insani Press.

Watt, W. Montgomery, 1968, Islamic Political Thought, North America: Edingburgh University Press 1969, Muhammad, Prophet And Statesman, London: Oxford University Press

Yatim, Badri, 1993, Sejarah Peradaban Islam, Jakarta: Rajawali Press 2001, Sejarah Peradaban Islam, Jakarta : PT. Grafindo Persada.

Zuhairini, dkk., 1986, Sejarah Pendidikan Islam, Jakarta : Departemen Agama 